\title{
Deixis y discurso
}

\section{Deixis and speech}

\author{
MIGUEL Á. PERDOMO-BATISTA \\ Universidad de Las Palmas de Gran Canaria, España. \\ Correo electrónico: miguel.perdomo@ulpgc.es
}

En este trabajo mostraremos cómo participa la deixis en la construcción metaficcional y metadiscursiva $y$, en general, en la construcción del sentido en el plano del discurso. A tal fin, examinaremos una fábula de Tomás de Iriarte y varias traducciones de esta, y mostraremos las consecuencias de esta función metadiscursiva. Para ello, y además de examinar los textos señalados, será preciso aclarar en lo posible la idea de deixis. Nuestro análisis se desarrolla en relación con la tradición gramaticográfica y la teoría de la enunciación.

Palabras claves: deixis, significado, enunciación, metaficción, pronombre.

In this work we will show how the deixis participates in the metafictional and metadiscursive construction, and, in general, in the construction of meaning at the level of discourse. To this end, we will examine a fable by Tomás de Iriarte and several translations of it and show the consequences of this metadiscursive function. In order to do this, and in addition to examining the texts indicated, it will be necessary to clarify as far as possible the idea of deixis. Our analysis is developed in relation to the gramaticography tradition and the theory of enunciation.

Key words: deixis, meaning, enunciation, metafiction, pronoun.

\section{SUMARIO:}

I. Introducción, 2. Marco teórico, 2.1. La deixis en la gramaticografía, 2.2 Deixis, teoría del lenguaje y lingüística, 3. Materiales y método, 4. Discusión y resultados. 5. Conclusiones, Obras citadas.

\section{Sumary:}

I. Introduction, 2. Theoretical framework, 2.1. The deixis in gramaticography, 2.2 Deixis, language theory and linguistics, 3. Materials and Methods, 4. Discussion and results, 5 . Conclusions. Cited works. 


\section{INTRODUCCIÓN}

Son variadas y complejas las categorías, las funciones y los planos de la lengua que pueden verse concernidos por el mecanismo de la deixis: el significado mostrativo de las unidades que la expresan, la determinación, tan importante en la arquitectura del idioma, la persona, la estructura informativa de la lengua y la modalidad, además de otros fenómenos que interesan a la crítica y la teoría literaria, como la cuestión del sujeto literario y los procesos metaficcionales, cuestiones de las que también nos ocuparemos. Esta complejidad nos obliga a extremar las precauciones en el análisis y la prudencia en las conclusiones, sobre todo si tenemos en cuenta que en las últimas décadas parece haberse diluido el consenso sobre el fenómeno de la deixis (Zamorano 2011: 209).

La deixis se halla relacionada, además, con la cuestión del sentido (exactamente con la distinción entre sentido y significado, la diferenciación del plano del lenguaje al que pertenece cada uno de ellos y la explicación de la interrelación de ambos), que es uno de los grandes problemas de la lingüística, un problema aparentemente esotérico lo llama Trujillo (1990: 113).

En este trabajo mostraremos que la deixis participa en la construcción metaficcional y metadiscursiva del texto literario, en el que los deícticos personales pueden interpretarse como elemento metaficcional, y consecuentemente en la construcción de formas discursivas de carácter satírico. Veremos también cómo contribuyen las unidades deícticas a la construcción del sentido del discurso. Para ello, examinaremos la deixis en una fábula de Tomás de Iriarte (1750, Islas Canarias, España-Madrid, 1791) comparando la versión original con varias traducciones al inglés para comprobar cómo resulta afectado el sentido del texto. En la traducción es importante un tratamiento delicado de las formas deícticas porque, de lo contrario, pueden anularse tales efectos (y también los efectos de la modalización). Veremos que, más que en las estructuras de la narración, la metaficción pone el énfasis en los procesos de construcción del sentido. Por lo demás, nuestro examen puede ayudarnos a comprender la contribución de la deixis a la construcción del sentido, y nos obligará a preguntarnos sobre la cuestión del sentido y el significado.

Para todo ello, y además de examinar el texto señalado, será preciso aclarar en lo posible el concepto de deixis, para lo cual nos proponemos realizar una revisión historiográfica del concepto en el apartado dedicado al marco teórico. Esta revisión seguirá una doble perspectiva: en primer lugar, las aportaciones de la gramaticografía, pues muchos de los avances se han hecho en relación con las teorías sobre el pronombre, el artículo, los determinantes o los posesivos. En segundo lugar, las aportaciones de la teoría del lenguaje, porque no es infrecuente que el examen de la deixis comprenda al mismo tiempo una teoría del lenguaje o se halle estrechamente vinculada con ella, como puede advertirse en los trabajos de Bühler (1985 [1934]), o Benveniste (1999 [1974]).

Como la deixis es uno de los temas recurrentes de la lingüística y las ideas sobre el lenguaje desde la Antigüedad, el bagaje acumulado al respecto es considerable, y tornan más intrincada la cuestión. Para aclarar y objetivar los términos, vamos a referirnos a la deixis tal 
y como se define en la Nueva Gramática de la lengua Española Manual de la Real Academia (2010: 327-328): La deixis es la propiedad que poseen muchas expresiones gramaticales para expresar significados que dependen de la posición que ocupen en el espacio o en el tiempo el hablante y el oyente. Y distingue, siguiendo a Bühler, entre deixis ostensiva (ad oculos) y deixis fórica (anafórica y catafórica) o intratextual; además de diferenciar, por el contenido semántico, entre deixis personal, temporal, locativa, cuantitativa y modal (nada se dice de la deixis social). No obstante, para algunos la cuestión no es tan sencilla. Coseriu (2016: 70-71), por ejemplo, señala la existencia de pronombres sustantivos, adjetivos, verbos e incluso pronombres propios (Fulano, Mengano, Zutano), descubiertos ya en el siglo XVII por Gonzalo Correas. Pero para nuestro propósito bastarán los límites de la definición académica.

\section{MARCo teórico}

Pocos dudarán de la contribución de las unidades deícticas a la construcción del sentido del texto, y menos aún de su contribución a las estructuras semántica e informativa de la lengua; cosa bien distinta es explicar cómo se efectúa esta. Y, ciertamente, la indagación sobre la deixis tiene lugar en el ámbito de la discusión sobre el significado. Benveniste, por ejemplo, afirma que el ser del lenguaje es el significado ${ }^{1}$. Se trata de una afirmación metafísica que sin embargo podemos asumir como aceptable. $\mathrm{Y}$ en una línea próxima, que no es otra que la de un estructuralismo fuertemente saussureano, se sitúan gramáticos como $\mathrm{M}$. Morera (1999) y semantistas como R. Trujillo (1988: 6) para afirmar, respectivamente, la naturaleza semántica de la gramática y el significado como instancia primaria en relación con las realidades expresables con palabras. Y lo cierto es que, si distinguimos entre el significado simbólico (o léxico) y el significado mostrativo, la deixis aparece entonces como un fenómeno de la significación primaria mostrativa, independientemente de su función textual (anafórica o catafórica). Sin embargo, en su concepción del estudio del significado, tanto Morera como Trujillo se alejan de Benveniste, que tal vez supone un esfuerzo por superar un paradigma lingüístico estructuralista demasiado apegado a la langue de Saussure.

Pero será mejor que vayamos poco a poco y retomemos el plan previsto al principio, pues, dentro de los límites posibles en un trabajo de este tipo, en la indagación sobre la deixis, puede sernos muy útil la revisión de las aportaciones de la gramaticografía a partir de la discusión sobre el pronombre (que es clave), el artículo (a menudo olvidado), los posesivos y los determinantes. Y en efecto, la mayoría de los elementos que intervienen en la discusión sobre la deixis la encontramos ya en la gramática alejandrina, en Dionisio de Tracia y, sobre todo, en Apolonio Díscolo (Manzanares 1997: 640-641).

\footnotetext{
${ }^{1}$ Lo afirma en un trabajo titulado "Forma y sentido del lenguaje" (Le Langage II, Société de Philosophie de langue Française, Actes du XIII ${ }^{e}$ Congrès, Genève, 1966, Neuchàtel, La Baconnière, 1967, pp. 29-40), recogido también en Poblemas de Lingüistica General (1999 [1974]: II, 219).
} 


\subsection{La deixis en la gramaticografía}

Efectivamente, en la gramática alejandrina encontramos ya enunciados, en relación con las ideas sobre el pronombre, las cuestiones fundamentales sobre las que girará la discusión sobre la deixis: 1) la idea del pronombre como sustituto, 2) su carácter de parte de la oración, como el artículo, 3) la persona gramatical como componente del pronombre, 4) la cuestión de la anáfora, 5) el significado de las unidades pronominales. Como veremos, una revisión de la gramaticografía sobre el pronombre (Manzanares 1997) puede ayudarnos a aclarar estas cuestiones.

Apolonio introdujo la persona y la deixis como contenido fundamental del pronombre (Manzanares 1997: 641); identifica persona y pronombre: lo que caracteriza a la persona es la deixis y a la inversa. A la deixis y la persona se une la determinación, porque lo designado deícticamente (lo que señala el pronombre) es lo presente en la actualidad del hablar. Podríamos decir que, a través de la deixis y la determinación, el lenguaje se encuentra con el mundo, se encarna en él. En el siglo XVIII, Harris también insistirá en la determinación como componente importante del pronombre, pues, con la excepción de los nombres propios, los contenidos lingüísticos no significan o aluden en sí mismos a lo individual (Manzanares 1997: 639). Así pues, y respecto del carácter sustitutorio del pronombre, podemos concluir que el pronombre no sustituye al nombre para evitar la repetición, sino porque hace algo que no puede hacer el nombre: señalar determinadamente (Manzanares 1997: 641), es decir, señala respecto de la actualidad del hablar, en el acto de la enunciación.

En cuanto a la anáfora, para Apolonio, en la $3^{a}$ persona la deixis toma la forma de anáfora, porque es textual. Ahora bien, debe advertirse que, como agudamente señaló Bello (1988 [1847]: 259-260), la deixis fórica recae sobre el tiempo del hablar, es decir, que el señalamiento textual es de orden temporal: lo dicho antes o lo que se dirá después en el decurso temporal de la enunciación, o, si se prefiere, y desde el punto de vista de la estructura informativa, lo ya dicho y lo nuevo. De modo que quizá lo más adecuado sea dejar de lado la cuestión. Bello define la $3^{\mathrm{a}}$ persona negativamente (como no $1^{\mathrm{a}}$ y no $2^{\mathrm{a}}$ ) (Manzanares 1997: 657).

En cuanto al significado del pronombre, para Apolonio (Manzanares 1997: 641), el pronombre sustituye porque es deíctico, y es deíctico porque es personal, pero su significación es indefinida al margen del contexto (lo que otros llamarán vacío significativo). Para los modistae y Apolonio, los significados pronominales constituyen una apprehensio indeterminata que se determina en el acto concreto del hablar (Manzanares 1997: 642), idea que nos sitúa en la línea de la teoría de la enunciación de Benveniste, como tendremos oportunidad de comprobar.

El Brocense (1976 [1587]: 52 y 505) consideraba que los pronombres eran nominadores primarios (los nombres más antiguos), formas gramaticales lingüísticamente primarias para la categorización de lo real, con relación a los cuales el léxico era secundario. Por su parte, y en la línea del racionalismo, Gómez Hermosilla (1837: 4-5) señalaba que la 
distinción entre signos que muestran y signos que nombran era clave de la ciencia gramatical. El tópico de la existencia de unos signos primarios o primeros signos en la aparición y evolución del lenguaje debe ser rechazado, como señala Bühler ${ }^{2}$. No obstante, ideas similares a las del Brocense y Hermosilla se hallan en la base de la distinción entre signos mostrativos y signos descriptivos, que es uno de los pilares de las teorías de Bühler. En la línea de Bühler y otros, Morera (1999) plantea la necesidad de distinguir en la significación primaria (no en la categorial) entre el significado simbólico o léxico y el mostrativo o pronominal. La deixis se nos aparece entonces como un fenómeno de la significación primaria mostrativa, independiente de su función textual (anáfora). Ni el pronombre ni el artículo poseerían entidad categorial propia, y no serían partes de la oración (Manzanares 1997: 638).

Coincidimos con Manzanares (1997: 650-651), que apela a Bello para afirmar la comunidad semántica (por la significación mostrativa) de personales, posesivos y demostrativos. Y en esa comunidad semántica ha de hallarse la clave de la pronominalidad. El significado mostrativo (la deixis) es independiente de lo categorial, y puede darse bajo cualquier categoría (persona verbal, adverbio, relativo). La pronominalidad parece un hecho de significación primaria, no categorial ${ }^{3}$. No obstante, para Coseriu (2016: 70), los pronombres son palabras que sólo tienen significado categorial sin significado léxico (sólo formas de lo aprehendido, sin el qué de lo aprehendido), y no son "«una parte de la oración", porque como parte de la oración, como categoría, pertenecen a todas las demás categorías". Pero creo que, al afirmar las posibilidades pronominales de cualquier categoría, Coseriu diluye el mismo carácter categorial del pronombre, por lo que habría que dar la razón a Morera (1999: 43-44) cuando afirma: Si hay algo que no caracteriza a los pronombres ese algo es precisamente la significación categorial. $\mathrm{Y}$ ańade, citando a $\mathrm{R}$. Seco, que el pronombre no se caracteriza por su función sintáctica, sino por su especial manera de significar los objetos.

Jakobson (1981 [1974]: 310), por su parte, incluye a los pronombres en una clase de signos a los que llama shifters o conmutadores -la terminología es de Jespersen-, de los que ofrece una interesante clasificación que permite deslindar las categorías gramaticales. Se trata de unidades dotadas de una doble naturaleza, porque son símbolos (su relación con el objeto representado es convencional) y también índices (relación existencial con el objeto señalado). Añade que la particularidad de los conmutadores no reside en la supuesta falta de un significado general constante (por lo cual se les consideraba meros índices), sino que, en realidad, cada conmutador posee su propio significado general: yo significa el

\footnotetext{
${ }^{2}$ Bühler (1985 [1934]: 105) nos previene contra este mito sobre el origen del lenguaje cuyo germen atribuye entre otros a Brugmann. Se trata del mito del origen deíctico del lenguaje representativo, que debe ser rechazado porque deixis y denotación son dos actos diferentes, demostrativos y nombres dos clases de palabras que deben ser distinguidas, de modo que es insuficiente la hipótesis de la prioridad temporal de un señalar original sin nombres.

${ }^{3}$ Creo que, aunque la lingüística racionalista supuso avances significativos en la teoría el pronombre y la deixis, de hecho, también complicó las cosas, porque entendió la deixis en términos de significado categorial y no primario, algo que se viene a superar definitivamente con Bühler (con el precedente de Humboldt). Se trata quizá de la insuficiencia de la semántica (o de una gramática no semántica) en los tiempos del racionalismo.
} 
destinador y tú, el destinatario. Así pues, para Jakobson, que parece augurar a Benveniste, los conmutadores son elementos metadiscursivos porque se distinguen de los demás elementos del código únicamente por su referencia obligatoria al mensaje en cuestión. Si aceptamos la propuesta de Jakobson, creo que todas las categorías deícticas, al actuar como conmutadores y referirse al mensaje, lo sitúan, y de este modo contribuyen de manera decisiva a la creación del sentido. Y a propósito de la transformación del significado en sentido, ¿̨no podría decirse también que los conmutadores facilitan la dialéctica entre la lengua y el habla?

\subsection{Deixis, teoría del lenguaje y lingüistica}

Los referentes insoslayables de las ideas sobre la deixis en el siglo XX son Bühler y Benveniste, aunque, como hemos visto, no deben olvidarse las aportaciones de Jakobson (1981 [1974]: 307-332) con sus ideas sobre los shifters. Uno de los fundamentos de la teoría de Bühler (1985 [1934], cap. 2 y 3) es la distinción entre campo mostrativo y campo simbólico del lenguaje, además del consabido modelo de organon del lenguaje cuyo precedente es el Crátilo de Platón (emisor-objetos-receptor > emisor-signo-receptor), que tienen su correlato en las tres funciones del lenguaje (cap. 1): expresiva-representativa-apelativa. Sin embargo, creo que, desde el punto de vista estrictamente comunicativo, la distinción entre emisor y receptor es delicada, y solo puede hacerse respecto de la iniciativa de uno u otro en la emisión verbal, porque ambos participan activamente en la construcción del sentido. En efecto, el receptor no está pasivo, porque contribuye al intercambio con el lenguaje no verbal, y proyecta su proceso inferencial sobre lo que dice el emisor, que, por lo demás, hace su propio cálculo inferencial sobre el efecto de sus palabras. La distinción entre un receptor (pasivo) y un emisor (activo) me parece poco sostenible. Si obviamos lo estrictamente verbal, no hay tal distinción entre emisor y receptor, lo que hay es significado, que los envuelve a ambos. Existe el significado porque existe el mundo (lo que desde luego no significa que podamos identificar o confundir ambos planos) y porque existe la conciencia, que es intencional, pues "darme cuenta de algo" es "darme cuenta de algo para mí", es decir, percibir el lugar que ocupa respecto de mí, su "función” para mí.

El modelo de Bühler, que es el punto de partida también para Jakobson (1981 [1974]: 307), establecido sobre una idea de la comunicación lingüística como sucesiva codificación y decodificación del mensaje, que muy probablemente tiene su fundamento en la distinción saussureana entre lengua y habla, parece insuficiente por las razones que acabamos de exponer y por otras que veremos después, y creo que es más adecuado el modelo ostensivo e inferencial surgido a partir del desarrollo de la pragmática, que concibe el mensaje como un estímulo interpretado por el receptor en un contexto. Este giro pragmático de la lingüística lo advertimos ya en las ideas de Benveniste (1999), que es el punto de partida de la Teoría de la Enunciación.

Benveniste parte de las ideas de Bühler para superarlas. Con él asistimos al paso de la lengua como sistema según Saussure, a la lengua como discurso. Distingue dos niveles de significación: el nivel semiótico, correspondiente al signo o la palabra y a la significación 
intralingüística dentro del sistema donde lo importante es distinguir; y el nivel semántico, correspondiente a la frase y a la situación dentro del discurso, donde la clave es comprender. Benveniste explica la deixis como una instancia de la enunciación, entendida esta como el acto mismo de producir un discurso. Comprender es percibir el significado de un enunciado en cada contexto enunciativo ${ }^{4}$.

Para Benveniste (1999 [1974]: 83-91) existen tres categorías abstractas de la enunciación: el Yo (aqui, ahora) corresponde al locutor, $1^{\text {a }}$ instancia del discurso; el Tú corresponde al alocutario, 2a instancia de la comunicación; Él y los demostrativos corresponden a la identificación de un objeto o hecho.

Como se advertirá, el planteamiento de Benveniste supone un avance en cuanto a la comprensión de la deixis personal, pero plantea también una cuestión discutida: la ubicación del sentido en el plano de la parole, y, por lo tanto, fuera de la lengua (y del estudio lingüístico para cualquier estructuralista inflexible). Pues en efecto, Benveniste distingue dos planos de la significación: el semiótico, que corresponde al signo o palabra y a la significación intralingüística; y el semántico, que corresponde al sentido en la situación del discurso. Ambos planos deben ser descritos de diferente modo:

Así, la enunciación es directamente responsable de ciertas clases de signos que promueve, literalmente, a la existencia. Pues no podrían nacer ni hallar empleo en el uso cognitivo de la lengua. Hay pues que distinguir las entidades que tienen en la lengua su estatuto pleno y permanente y aquellas que, emanadas de la enunciación, solo existen en la red de "individuos" que la enunciación crea y en relación con el "aquí-ahora" del locutor. Por ejemplo, el "yo", el "eso", el "mañana" de la descripción gramatical no son sino los "nombres metalingüísticos del Yo, eso, mańana producidos en la enunciación (Benveniste, 1999 [1974]: II, 86-87).

Y señala que tal distinción y la explicación de la interacción entre los dos planos es una de las cuestiones pendientes de la Lingüística:

La enunciación supone la conversión individual de la lengua en discurso. Aquí la cuestión -muy difícil todavía y poco estudiada- es ver cómo el "sentido" se forma en "palabras", en qué medida puede distinguirse entre las dos nociones y en qué términos escribir su interacción. Es la semantización de la lengua la que ocupa el centro de este aspecto de la enunciación, y conduce a la teoría del signo y al análisis de la significancia (Benveniste, 1999 [1974]: II, 83-84).

Pero para Trujillo, por ejemplo, el terreno del saber lingüistico es el de la competence; la interpretación lingüistica de la realidad corresponde a la performance:

\footnotetext{
${ }^{4}$ En la síntesis de las ideas de Benveniste sigo a Bertorello (2008: 45-53).
} 
El punto de vista de la lengua, por el contrario, es el de la percepción del significado como tal significado, con independencia de que, al margen de la lengua, puedan hacerse toda clase de intentos interpretativos, relacionando los mensajes lingüísticos con realidades concretas (Trujillo 1990: 119 y 120).

Llegamos así a lo que podríamos denominar la aporía del significado, pues en efecto, siendo este de naturaleza estrictamente lingüística, queda fuera de la lengua al transformarse en sentido en el discurso. Si, como afirma Trujillo (1990: 116), cualquier signo tiene la posibilidad de significar cualquier cosa, hallamos aquí una contradicción, porque tal posibilidad debe darse en el habla. Creo que en la tesis de Trujillo se confunde un hecho de naturaleza epistémica, la necesidad de que el significado sea estudiado por la semántica en el estricto plano de la lengua (algo que Benveniste podría suscribir), y otro hecho de naturaleza ontológica, la realidad dialéctica del significado como sentido, que surge de la interacción entre lengua y habla. Por eso afirma Meix (1994):

En consecuencia, y frente al punto de vista de Trujillo (R. Trujillo, 90), creemos que los significados no existen antes y aparte de las interpretaciones concretas, sino que se revitalizan en el acto mismo de la interpretación. Lo que sí existe es la inercia de las interpretaciones anteriores, y a esa inercia el diccionario la llama "significado", otorgándole una consistencia y un espesor que inducen al fetichismo (219).

Creo que ni el mismo Saussure sería tan intransigente en la distinción dicotómica entre langue y parole, porque como señala en el Cours: Hay pues interdependencia de lengua y habla: aquella es a la vez el instrumento y el producto de esta (Saussure 2002 [1916]: 64). Así es que el maestro de Ginebra parece orientarnos hacia una concepción dialéctica. Es verdad que a continuación afirma que al hacer la teoría del lenguaje Hay que elegir entre dos caminos que es imposible recorrer a la vez; tienen que ser recorridos por separado. Pero, como hemos señalado, creemos que esta es una afirmación de carácter epistémico, no ontológico. La explicación de Trujillo es de tipo pragmático, porque lo que le interesa como semantista es cómo puede ser estudiado el significado. A partir de esa concepción dialéctica del lenguaje, Meix sostiene:

la actividad del significar es radicalmente interpretativa. La interpretación es una competencia plenamente lingüística desde el momento en que la vitalidad del lenguaje se sustenta en una tensión recodificadora permanente que le permite adaptarse e intervenir eficazmente en las nuevas situaciones de la vida social (Meix 1994: 219).

Así pues, para superar la aporía señalada, creo que deberíamos considerar algún tipo de "injerencia" de la parole en la langue. Y ello reclama una orientación pragmática de la Lingüística, sin que ello deba conducirnos a los errores metodológicos del pasado. 
Y en este sentido quizá convenga recordar a Rauh cundo señala que la dependencia de las expresiones deícticas de la situación del emisor sugiere que la descripción de la deixis pertenece al componente pragmático de la gramática (Gargiulo 1999: 14).

\section{Material y MÉTOdos}

Como se habrá advertido, en el apartado anterior hemos adoptado una perspectiva historiográfica para aclarar algunas cuestiones y situar el problema de la deixis en el contexto adecuado. En el siguiente apartado me propongo aplicar las ideas expuestas sobre un texto literario de Tomás de Iriarte para examinar cómo la deixis contribuye a la creación del efecto metadiscursivo y metaficcional, y a la modalización.

El texto en cuestión es el primero de una colección de apólogos reunidos bajo el título de Fábulas Literarias y publicadas por primera vez en Madrid en 1782. La fábula se titula El elefante y otros animales y sirve de prólogo a la colección, de modo que actúa como referente textual de toda la obra ${ }^{5}$. Las Fábulas literarias constituyen una de las principales obras de la literatura espańola del siglo XVIII, y seguramente la más conocida de su época en el exterior. En nuestro análisis compararemos el texto de la edición española con algunas versiones inglesas. Transcribo a continuación el texto completo, en el que he respetado la puntuación y la ortografía original.

Antes de iniciar el análisis, parece oportuno contextualizar el texto dentro de la obra del autor y de su época.

En cuanto a su autor, Tomás de Iriarte (1750-1791), es preciso señalar que fue una de las personalidades más destacadas de la Ilustración española. Era hermano del diplomático Domingo de Iriarte y del político Bernardo de Iriarte. Los tres hermanos procedían de las Islas Canarias (Espańa), y fueron educados en Madrid por su tío Juan de Iriarte y Cisneros, bibliotecario real, miembro de la Real Academia Española e importante gramático latino (Iriarte y Cisneros 1771). Puede decirse que las Fábulas Literarias de Iriarte son la innovación más radical del género fabulístico desde la Antigüedad. Ello se debe en gran medida a que su temática es exclusivamente literaria. En efecto, estos apólogos tratan del sentido y la naturaleza de la actividad literaria.

Hay que interpretar la obra en relación con una de las características de la Ilustración española: las encendidas polémicas literarias, en las que se discute el valor y la naturaleza de la actividad de los autores o el valor y la finalidad de la literatura. Podría decirse que las polémicas literarias del siglo XVIII van dibujando, a través del discurso satírico, una especie de deontología literaria de la época que adquiere su máxima expresión en las Fábulas. Por ello, podríamos considerar a Iriarte un reformador literario a través del lenguaje satírico de esta obra.

\footnotetext{
${ }^{5}$ También van al principio del I tomo de la Colección de obras en verso y prosa en las ediciones de 1787 y 1805 , lo que nos indica el valor y el significado que tenía la obra para el autor, que la sitúa al frente de sus obras completas.
} 


\section{PRÓLOGO \\ FÁBULA PRIMERA}

\section{El Elefante y otros Animales}

Allá en tiempo de entónces, $\mathrm{Y}$ en tierras mui remotas Quando hablaban los Brutos Su cierta gerigonza, Notó el sabio Elefante Que entre ellos era moda Incurrir en abusos Dignos de gran reforma. Afeárselos quiere; $\mathrm{Y}$ á este fin los convoca. Hace una reverencia A tódos con la trompa; Y empieza á persuadirlos En una arenga docta Que para aquel intento Estudió de memoria. Abominando estuvo Por más de un quarto de hora Mil ridículas faltas, Mil costumbres viciosas: La nociva pereza, La afectada bambolla, La arrogante ignorancia, La envidia maliciosa.

Gustosos en extremo, Y abriendo tanta boca, Sus consejos oían Múchos de aquella tropa: El Cordero inocente, La siempre fiel Paloma, El leal Perdiguero, La Abeja artificiosa, El Caballo obediente, La Hormiga afanadora, El hábil Xilguerillo, La simple Mariposa Pero del auditorio Otra porción no corta Ofendida, no pudo Sufrir tanta parola. El Tigre, el rapaz Lobo Contra el Censor se enojan. ¡Qué de injurias vomita
La Sierpe venenosa! Murmuran por lo baxo Zumbando en voces roncas El Zángano, la Abispa, El Tábano, y la Mosca. Sálense del concurso, Por no escuchar sus glorias, El Cigarrón dañoso, La Oruga y la Langosta. La Garduña se encoje; Disimula la Zorra, Y el insolente Mono Hace de tódo mofa.

Estaba el Elefante Viéndolo con pachorra; Y su razonamiento Concluyó en esta forma: A tódos y á ninguno Mis advertencias tocan: Quien las siente, se culpa; El que nó, que las oiga.

Quien mis Fábulas lea, Sepa también que tódas Hablan á mil Naciones, No sólo á la Española. $\mathrm{Ni}$ de estos tiempos hablan; Porque defectos notan Que hubo en el mundo siempre, Como los hai ahora. Y pues no vituperan Señaladas personas, Quien haga aplicaciones, Con su pan se lo coma (Iriarte 1782: 1-4). 
Como señala Francisco Uzkanga (2001: 425 y ss.), la sátira alcanzó su punto álgido en la literatura dieciochesca. Pero no se trata ahora de corregir al pecador, sino a quien se extravía de la razón, porque el discurso satírico se seculariza y se transforma en un instrumento didáctico. El origen de esta nueva dimensión hay que buscarlo en Inglaterra, en los editores de The Spectator y The Tatles. Por ello, se nos antojan las Fábulas como la culminación del proceso de secularización de la sátira en el siglo XVIII.

\section{DisCuSión y RESUltados}

La fábula El elefante y otros animales comienza con una doble deixis de carácter temporal y espacial. Veámoslo.

\section{Allá en tiempo de entonces, \\ $\mathrm{Y}$ en tierras mui remotas}

Se trata de una locución deíctica introducida por el adverbio demostrativo de lugar allá, que tiene un significado comúnmente ostensivo y expresa distancia respecto al acto de enunciación establecido por el narrador. No designa un punto o localización específicos, sino que más bien se refiere a un área o zona (RAE 2010: 340).

El adverbio va seguido de la aposición explicativa en tiempo de entonces (así lo interpretan también los editores modernos, que la separan con una coma [Prieto 2004: 117]) de valor temporal cuyo núcleo es un sustantivo de denotación temporal. Creo que el carácter deíctico, esto es, la naturaleza referencial (acaso pronominal) del adverbio allá es lo que facilita precisamente la construcción en aposición. El núcleo de la aposición va seguido, además de un complemento del nombre (de entonces) formado por la preposición más el sintagma adverbial entonces, que muestra también propiedades pronominales y de nuevo hace deixis anafórica hacia aquel tiempo, de modo que reitera la referencia temporal lejana e imprecisa. A continuación, el tiempo pasado de las formas verbales, que corresponden al primer plano (pretérito perfecto: notó) y segundo plano de la narración (imperfecto: hablaban, era), reiteran la deixis hacia ese pasado propio de la narración. Por su parte, el presente (afeárselos quiere, convoca, hace) establece un vínculo con el presente de la enunciación de efecto satírico, pues lo dicho entonces corresponde también al ahora de la enunciación.

En síntesis, lo que tenemos en el primer verso es una expresión de la lengua común, sólo en apariencia sencilla, que expresa una referencia temporal lejana e imprecisa. En realidad, creo que es una mera variante de la locución adverbial temporal "en aquel entonces" o "por aquel entonces". La diferencia es que, en la expresión que analizamos, la deixis temporal está más marcada. Va seguida, en relación de coordinación copulativa, de un sintagma con preposición de valor locativo ( $y$ en tierras muy remotas) que reitera la idea de lejanía, en este caso espacial. 
Lo que me interesa de esta doble deixis temporal y espacial es que se trata de una deixis en fantasma (am phantasma) según la clasificación de Bühler (1985 [1934]: 141), pues remite a un tiempo y espacio lejanos al de la enunciación narrativa y que no es otro que el de la fantasía (la ficción) y, por tanto, el de la fábula. Como él mismo señala:

Pero las circunstancias cambian de golpe, por lo visto, cuando un narrador lleva al oyente al reino de lo ausente recordable o al reino de la fantasía constructiva y lo obsequia con los mismos demostrativos, para que vea y oiga lo que hay que ver y oír [...]. No con los ojos, oídos, etc., exteriores, sino [...] "interiores" o "espirituales" (Bühler 143).

Estimo que no es inútil distinguir la deixis en fantasma de la deixis ad oculos y la deixis fórica, pues en la primera no hay continuidad existencial entre lo señalado y el locutor y alocutario (sí hay, naturalmente, continuidad histórica o cognitiva, que es precisamente lo que permite esa deixis en fantasma). Pero tal distinción, basada en la situación, no me parece esencial, y creo que solo tiene consecuencias para la taxonomía, porque el funcionamiento del mecanismo deíctico es el mismo (el receptor no puede ver o escuchar lo señalado, pero es llevado a donde podría verlo y oírlo si estuviera allí, es decir, al espacio de la fantasía).

Creo que la locución deíctica Allá en aquel tiempo de entonces es similar a otras que caracterizan el inicio del relato en la literatura oral: En aquel tiempo, Érase una vez, Érase que se era, Habia una vez, etc. Para expresarlo en los términos de van Dijk (1980 [1977]: 325339), desde el punto de vista semántico y pragmático se trata de fórmulas que expresan una función narrativa que configura un macroacto discursivo de carácter narrativo. Pero todo es producto de la instancia enunciativa de la narración, del yo, aqui, ahora del narrador. Y aunque en el ejemplo analizado, la deixis no provoca un efecto metadiscursivo, sí genera, desde luego, un efecto discursivo que trasciende la mera ostensión: el de remitir a la ficción narrativa, cuyo correlato en la enunciación escrita es la relación literaria. También se alude a estas fórmulas introductorias en las que el tiempo señala al mundo narrado en el trabajo clásico de Harald Weinrich (1974 [1964]: 81-84).

El segundo ejemplo que vamos a analizar aparece al final de la fábula: Quien mis fábulas lea / sepa también que todas. Hallamos de nuevo dos ejemplos de deixis, la del pronombre que introduce la relativa libre, que se repite en el penúltimo verso, y la deixis del posesivo (mis fábulas), retomada enseguida por el anafórico todas y por la $3^{\mathrm{a}}$ persona de todas las formas verbales hasta el final. Hablaremos en ambos casos de deixis personal, pues, como se sabe, el relativo quien contiene dos componentes gramaticales, uno nominal (la persona) y otro relativo (que), de modo que remite de forma indeterminada a cualquier lector futuro (los del pasado quedan excluidos por el modo verbal subjuntivo: lea), sin excluir al lector presente, (es la "agrupación" de posibles lectores, que incluye al lector presente) en el momento de la enunciación escrita, de modo que quien mis fábulas lea equivale también a 'Tú, lector'. En los términos de Benveniste, hay una deixis personal a la $2^{\mathrm{a}}$ instancia de la enunciación, precedida de una deixis a la $1^{\mathrm{a}}$ instancia, expresada por la $1^{\mathrm{a}}$ 
persona del posesivo. Ambas deixis personales al autor y al lector (emisor y receptor) dentro de la propia enunciación narrativa provocan un efecto metaficcional y metadiscursivo que me parece destacable, pues es el responsable de la orientación satírica de esta fábula y aun de todas las demás, porque esta es la primera y sirve de referente, y además se introduce el anafórico todas. En este ejemplo, el posesivo y el relativo son expresiones idiomáticas de la persona que designan, en el plano óntico, al autor enunciador y al lector enunciado. Las instancias de la enunciación conectan el plano lingüístico con el óntico (la designación se une al significado para conformar el sentido).

Ya hemos comentado el valor de la sátira en el contexto de la obra y la época de Tomás de Iriarte, pues a través del discurso satírico que se apoya en la metaficción (las Fábulas literarias son una reflexión crítica sobre lo literario, y consecuentemente sobre sí mismas), constituyen una suerte de deontología de lo literario. Por lo demás, la deixis al enunciador (mis fábulas), que reclama así su control sobre la enunciación, y el enunciado desiderativo (conformado sobre el relativo quien y la forma paradigmática subjuntiva lea), instauran una modalidad enunciativa de carácter deóntico, pues se establece cómo deben ser interpretadas (todas) las fábulas de Iriarte, si bien la modalidad de la enunciación no es propiamente imperativa.

No podemos omitir las referencias deícticas que se establecen al final de la fábula, que vienen a reforzar nuestra interpretación:

[Mis fábulas] Hablan á mil Naciones,

No sólo á la Española.

$\mathrm{Ni}$ de estos tiempos hablan;

Porque defectos notan

Que hubo en el mundo siempre,

La $2^{\text {a }}$ instancia de la enunciación se desdobla en un "tú, lector" y aquellos a los que se dirigen (Hablan á mil Naciones), ambos se confunden, de modo que el efecto satírico resulta evidente y se intensifica. Y no podemos pasar por alto, además, la maravillosa deixis temporal del final:

\author{
Ni de estos tiempos hablan; \\ Porque defectos notan \\ Que hubo en el mundo siempre, \\ Como los hai ahora.
}

Sustentada sobre el sintagma estos tiempos (adviértase el valor del demostrativo), el presente de indicativo de las formas verbales y el adverbio ahora, la deixis está apuntando claramente al tiempo de la enunciación, y ello resulta esencial no solo para el efecto satírico, sino para el propósito de la fábula y, por tanto, para establecer su sentido final.

Los efectos que hemos ido señalando desaparecen o se debilitan mucho si se omite la deixis personal sobre la que se apoya el efecto metadiscursivo y metaficcional, lo que 
debe tenerse muy en cuenta en la traducción, como veremos en seguida. Presentamos a continuación una traducción temprana al inglés en la que se mantiene la deixis.

Readers -my fables, be it known,

Are not addressed to you, alone,

(For all the world may justly claim

To share their moral, and their blame,)

Nor only to the present times;

For literary faults, and crimes,

Such as obtain their censure free,

Have ever been, will ever be.

Here, then, I openly disclaim

All personal and private aim.

If any, notwithstanding, will

Take a mere general lesson ill,

Because it suits himself, -I say,

Let him digest it as he may (Andrews 1835: 4-5).

En la traducción anterior, la deixis personal de carácter metaficcional no se ha eliminado, sino que acaso resulta más evidente por el vocativo inicial y el pronombre de $2^{\text {a }}$ persona. En el siguiente ejemplo también se mantiene la deixis personal de la $1^{a}$ persona, aunque el traductor seńala en el prólogo que se trata de una traducción libre.

My fables, in their application,

Refer to every age and nation;

For authors, just as dull and vain

As any who abound in Spain,

Have perpetrated prose and rhyme

In every land, in every time.

But, though I solemnly disclaim

All personality off aim,

If any scribbler, conscience-smitten,

Should wince at aught that I have written-

Should find, in short, the cap to fit,

The fool is welcome unto it (Rockliff 1846: 5).

El siguiente ejemplo corresponde a una imitación (una recreación) de las fábulas, bien que su autor se reconoce como translator (p. 31) en la Introducción, y se señala (p. 29): he has ventured to imitate, as nearly a posible, the various beauties of the original (se ha aventurado a imitar, lo más posible, las diversas bellezas del original). Como se comprobará, la $1^{\text {a }}$ persona se ha omitido. 
Now be it known, from bussines fred,

To those, who may these Fables read,

To no one party are addrest [sic]

Thoughts, or remarks, in them exprest [sic]:

Vices I note, and faults, 'tis true,

Yet not the faults of om or Hugh;-

But such as all my plainly see,

Who nature view, as well as me- (Belfour 1804: 39).

En efecto, en who may these Fables read la deixis a la $1^{\text {a }}$ persona ha desaparecido, y aunque el efecto metafictional se mantiene gracias al demostrativo, que señala a la fábulas de las que él mismo texto forma parte (these Fables), queda desdibujado, pues la referencia metadiscursiva es posible solo porque sabemos de qué fábulas se trata y quién es su autor (en efecto, de no ser así, ja qué fábulas se refiere el demostrativo these?). El texto ha perdido su autonomía, porque si lo extraemos de la colección de apólogos como entidad independiente, la posibilidad de deixis desaparece, y con ella la referencia metadiscursiva y metaficcional, y con ambas el șẹntịḍo último de esta y las demás fábulas (corregir los "vicios literarios" a partir de una deontología literaria formulada en clave satírica). En cuanto al relativo (who), su funcionamiento me parece similar al de la versión española. Por lo demás, como desaparece la referencia deíctica al autor (Iriarte), creo que se diluye el valor satírico y crítico (ya no es Iriarte contra sus detractores y émulos). Se pierde al menos parte del artificio literario, que en el género satírico es muy importante por lo que tiene de lúdico (el referente, más o menos claro, siempre está presente) con las consecuencias que esto pueda tener para su valor como obra literaria.

Hemos analizado una sola fábula, pero las referencias deícticas al autor o al lector que provocan un efecto metadiscursivo y metaficcional son muy abundantes en toda la colección. Sirvan como ejemplo, las siguientes fábulas: La abeja y los zánganos (Prieto 2004: 123-124), La hormiga y la pulga (Prieto 2004: 133), La parietaria y el tomillo (Prieto 2004: 135), Los dos conejos (Prieto 2004: 137), El caminante y la mula de alquiler (Prieto 2004: 148), El ratón y el gato (Prieto 2004: 153-154), El gozque y el macho de noria (Prieto 2004: 167-169).

\section{Conclusiones}

Benveniste (1999 [1974]: II, 91) distingue la enunciación hablada de la escrita, porque esta se mueve en dos planos: el escritor se enuncia escribiendo, y dentro de su escritura, hace que se enuncien individuos. Esta es precisamente la perspectiva que hemos querido adoptar en nuestra aplicación de su teoría de la enunciación al texto literario. Hemos comprobado cómo el escritor se enuncia a sí mismo explícitamente como locutor (mis fábulas) desde la escritura, provocando de este modo un efecto metadiscursivo y metaficcional que es 
decisivo en la construcción del sentido final, y que en nuestro ejemplo favorece el juego satírico. Cuando no se trata de deixis personal, el señalamiento también puede generar un efecto discursivo que trasciende la mera ostensión: el de remitir a la ficción narrativa, cuyo trasunto en la enunciación escrita es el relato literario. Si se elimina el juego deíctico se pierde al menos parte del artificio literario, con las consecuencias que esto puede tener para el valor de la obra en el caso de las piezas de carácter satírico, en las que lo metaficcional (y lo referencial) son componentes muy importantes.

Hemos visto que, más que en las estructuras de la narración, la metaficción pone el énfasis en los procesos de construcción del sentido a través de mecanismos como la deixis. No en vano, podría interpretarse la metaficción y el metadiscurso como una deixis hacia la enunciación (como proceso o hacia sus elementos). Nuestro análisis también parece sugerirnos que los distintos tipos de deixis corresponden a un único fenómeno esencial que afecta a categorías diversas y cuya base es el significado primario mostrativo. Este es el elemento esencial de pronombres y demostrativos, y por tanto de la deixis, que se nos muestra así como un mecanismo unitario. Nos sugiere también que el pronombre carece de significado categorial, y que las unidades deícticas parecen formar parte del componente pragmático de la gramática.

En cualquier caso, nuestro examen se ha desarrollado en el ámbito de la discusión sobre el significado y el sentido. Y en este particular, el modelo establecido a partir de una idea de la comunicación lingüística como sucesiva codificación y decodificación del mensaje parece insuficiente, lo que sugiere la oportunidad de un modelo ostensivo e inferencial que tenga en cuenta las aportaciones de la pragmática. En tal sentido, la propuesta de Benveniste se adapta muy bien al análisis que hemos realizado de la deixis, y facilita la explicación del alcance del fenómeno deíctico en el texto literario examinado. Creo que las categorías deícticas son muy importantes en la construcción del sentido, porque facilitan la dialéctica entre lengua y habla.

\section{Obras CITADAS}

Andrews, Richard. 1835. Literary fables from the Spanish of Yriarte. Smith: Elder and Company.

Belfour, John. 1804. Fables on subjects connected with literature imitated from the Spanish of Don Tomas de Yriarte. London: Wittingham.

Bello, Andrés. 1988 [1847]. Gramática de la lengua castellana destinada al uso de los americanos. Edición de R. Trujillo. 2 vols. Madrid: Arco Libros. Citamos esta obra por párrafos, según la numeración usual desde Cuervo.

Benveniste, Émile. 1999 [1974]. Problemas de lingüistica general, t. II. México: Siglo XXI. Bertorello, Adrián. 2008. El límite del lenguaje. La filosofía de Heidegger como teoría de la enunciación. Buenos Aires: Biblios.

Bühler, Karl. 1985 [1934]. Teoría del lenguaje. Trad. de Julián Marías. Madrid: Alianza 
Editorial.

Dijk, Teun van. 1980 [1977]. Texto y contexto. Semántica y pragmática del discurso. Trad. de Juan Domingo Moyano. Madrid: Cátedra.

Coseriu, Eugen. 2016. La semántica en la lingüistica del siglo XX: tendencias y escuelas. Pról. de Gregorio Salvador, edición e introducción de Maximiano Trapero. Madrid: Arco/ Libros.

Devereux, George. 1855. Literary Fables of Yriarte, translated from the Spanish [Fábulas literarias de Iriarte, traducidas del castellano]. Boston: Ticknor and Fields.

Díscolo, Apolonio. 1987. Sintaxis. Traducción, introducción y notas de Vicente Bécares Botas. Madrid: Gredos.

Gargiulo, Hebe. 1999. Espacio, deixis y traducción. San Juan: Argentina.

Gómez Hermosilla, José. $1837^{2}$. Principios de gramática general. Madrid: Imprenta Nacional.

Harris, James. 1972 [1751]. Hermes or a philosophical inquiry concerning language and universal grammar. Puede consultarse la clásica traducción francesa (con importantes notas y observaciones) de François Thurot, Hermès ou recherches philosophiques sur la grammaire universelle. París, 1796 (Ed. facsímil de André Joly, Ginebra: Libraire Droz).

Iriarte y Cisneros, Juan de. 1771. Gramática latina [...]. Madrid: Pedro Marín. Se imprimió muchas veces dentro y fuera de España. En América, conocemos la edición simultánea de R. Ackermann en 1826 en Londres, México, Colombia, Buenos Aires, Chile, Perú, Guatemala. Hay otra edición posterior de 1832.

Iriarte, Tomás de. 1782. Fábulas literarias. Madrid: Imprenta Real. . 1805. Fábulas Literarias. En Tomás de Iriarte, Colección de obras en verso y prosa de D. Tomás de Yriarte, T. I. Madrid: Imprenta Real.

Jakobson, Roman. 1981, 2a ed. [1974]. Ensayos de lingüistica general. Trad. de Josep M. Pujol y Jem Cabanes. Barcelona - Caracas - México: Seix Barral.

Manzanares, Antonio. 1997. Pronombre y teoría del lenguaje en las gramáticas españolas del siglo XIX. Tesis Doctoral, Universidad de Las Palmas de Gran Canaria, Las Palmas de Gran Canaria (España). Disponible en: https://acceda.ulpgc.es/handle/10553/1/ simple-search?query=manzanares [Consulta: 20/02/2019].

Morera, Marcial. 1999. Apuntes para una gramática del español de base semántica. Primera parte: Morfología. Puerto del Rosario: Cabildo de Fuerteventura.

Meix, Francisco. 1994. La dialéctica del significado lingüistico. Salamanca: Ediciones Universidad de Salamanca.

Prieto de Paula, Ángel. 2004. Tomás de Iriarte, Fábulas literarias. Edición e introducción. Madrid: Cátedra.

Real Academia Espańola. 2010. Nueva Gramática de la Lengua Española, Manual. Madrid: Espasa Libros.

Rockliff, Robert. 1846. Literary Fables from the spanish of Yriarte. London. Longmans: Green and Co. 
Sánchez de las Brozas, Francisco. 1976 [1587]. Minerva o de la propiedad de la lengua latina. Madrid: Cátedra.

Saussure, Ferdinand. 2002 [1916]. Curso de Lingüistica general. Publicado por Charles Bally y Albert Sëchéhaye con la colaboración de Albert Riedlinger. Traducción, prólogo y notas de A. Alonso, presentación de Ignacio Bosque. Argentina - España: Losada.

Tracia, Dionisio de. 2002. Gramática. Comentarios antiguos. Introducción y traducción de Vicente Bécares Botas. Madrid: Gredos.

Trujillo, Ramón. 1988. Introducción a la semántica española. Madrid: Arco/Libros.

Trujillo, Ramón. 1990. 2-6 de abril. "Semántica y gramática: sobre la capacidad sintáctica del diccionario". En M. Ángeles Álvarez (ed.), Actas del Congreso de la Sociedad Española de Lingüistica. Madrid: Gredos. 112-132.

Uzkanga, Francisco. 2001. "Ideas de la sátira en el siglo XVIII: hacia una nueva función en el marco de la ideología ilustrada". Revista de literatura 126.63: 425-460.

Vicente, Juan Antonio. 1990. "Deixis y conocimiento". Anales de filología hispánica 5: 145154.

Weinrich, Harald. 1974 [1964]. Estructura y función de los tiempos en el lenguaje. Trad. de Federico Latorre. Madrid: Gredos.

Zamorano, Alfonso. 2011. "Conceptualización y conciencia metalingüística de la deixis espacial en la teoría lingüística española del siglo XIX". En C. Sinner, Ma J. García y A. Zamorano (eds.). Estudios historiográficos. Tiempo, espacio y relaciones espaciotemporales en la lengua española. Hamburgo: Helmut Buske Verlag. 206-227. 